\title{
RGD targeting of human ferritin iron oxide nanoparticles can enhance in vivo carotid MRI of experimental atherosclerosis
}

\author{
Toshiro Kitagawa $^{1 *}$, Hisanori Kosuge ${ }^{1}$, Masaki Uchida² ${ }^{2}$ Trevor Douglas ${ }^{2}$, Michael V McConnell ${ }^{1}$ \\ From 2011 SCMR/Euro CMR Joint Scientific Sessions \\ Nice, France. 3-6 February 2011
}

\section{Background}

Human ferritin (HFn) is a promising nanoscale protein cage platform for molecular/cellular imaging, and we have developed engineered HFn nanoparticles as MRI agents. Inflammation and angiogenesis contribute to atherosclerosis, and RGD is a well-studied ligand of the $\alpha_{v} \beta_{3}$ integrin expressed by activated macrophages and angiogenic endothelial cells.

\section{Purpose}

To evaluate RGD-conjugated HFn-iron oxide nanoparticles for enhanced in vivo MRI detection of murine carotid atherosclerosis.

\section{Methods}

1) Mice

Fourteen FVB mice underwent left carotid ligation after 4 weeks of high-fat diet and diabetes induction by streptozotocin.

\section{2) RGD-conjugated HFn-iron oxide nanoparticles}

Using the recombinant human heavy-chain ferritin protein cage, HFn was genetically engineered to display 24 copies of an RGD-4C peptide (CDCRGDCFC) on the exterior surface of the protein cage. Magnetite $\left(\mathrm{Fe}_{3} \mathrm{O}_{4}\right)$ was encapsulated in interior cavities of RGD-conjugated HFn (RGD ${ }^{+}$HFn) and non-targeted HFn (RGD ${ }^{-}$HFn) at loading factors of $5000 \mathrm{Fe}$ per cage, giving R2 values of $93 \mathrm{mM}^{-1} \mathrm{~s}^{-1}$ (magnetite diameter: 5-7nm, exterior diameter: $12 \mathrm{~nm}$ ). The injected dose was adjusted to $25 \mathrm{mgFe} / \mathrm{kg}$.

${ }^{1}$ Stanford University School of Medicine, Stanford, CA, USA

Full list of author information is available at the end of the article
3) MRI

Two weeks post ligation, mice were imaged on a wholebody 3T MRI scanner (Signa HDx, GE Healthcare) with a phased array mouse coil (RAPID MR International), using a gradient echo sequence $(\mathrm{TR} / \mathrm{TE}=100 \mathrm{~ms} / 10 \mathrm{~ms}$, slice thickness $=1.0 \mathrm{~mm}, \mathrm{FOV}=3 \mathrm{~cm}$, matrix $=256 \times 256$, $F A=60, N E X=10)$. Mice were then injected with either $\mathrm{RGD}^{+}(\mathrm{n}=7)$ or $\mathrm{RGD}^{-}(\mathrm{n}=7)$ HFn nanoparticles, followed by MRI at 24 and 48 hours post injection. The nanoparticle accumulation was assessed by measuring the extent of $\mathrm{T} 2 \%$-induced reduction in carotid lumen size (\% reduction of carotid lumen area).

\section{4) Histology}

Perl's iron staining was performed to identify accumulation of the nanoparticles in the carotid lesions.

\section{Results}

Both $\mathrm{RGD}^{+}$and $\mathrm{RGD}^{-}$HFn nanoparticles caused a reduction in lumen size of the ligated left carotid arteries at $48 \mathrm{hrs}$ due to $\mathrm{T} 2^{*}$ signal loss $(\mathrm{p}<0.001$ vs. preinjection, Figures 1,2 ), but the effect was significantly greater with $\mathrm{RGD}^{+} \mathrm{HFn}\left(\mathrm{p}=0.01\right.$ vs. $\mathrm{RGD}^{-} \mathrm{HFn}$ ). There was no significant lumen reduction in the non-ligated (control) right carotid arteries. Perl's iron staining confirmed greater accumulation of $\mathrm{RGD}^{+} \mathrm{HFn}$ in the lesion compared to RGD ${ }^{-} \mathrm{HFn}$, primarily in neointimal macrophages (Figure 3).

\section{Conclusions}

Human ferritin protein cage is a versatile nanoparticle imaging platform for in vivo cellular/molecular MRI, with enhanced atherosclerosis imaging through multivalent RGD targeting.

\section{C) Biomed Central}

(c) 2011 Kitagawa et al; licensee BioMed Central Ltd. This is an open access article distributed under the terms of the Creative Commons Attribution License (http://creativecommons.org/licenses/by/2.0), which permits unrestricted use, distribution, and reproduction in any medium, provided the original work is properly cited. 


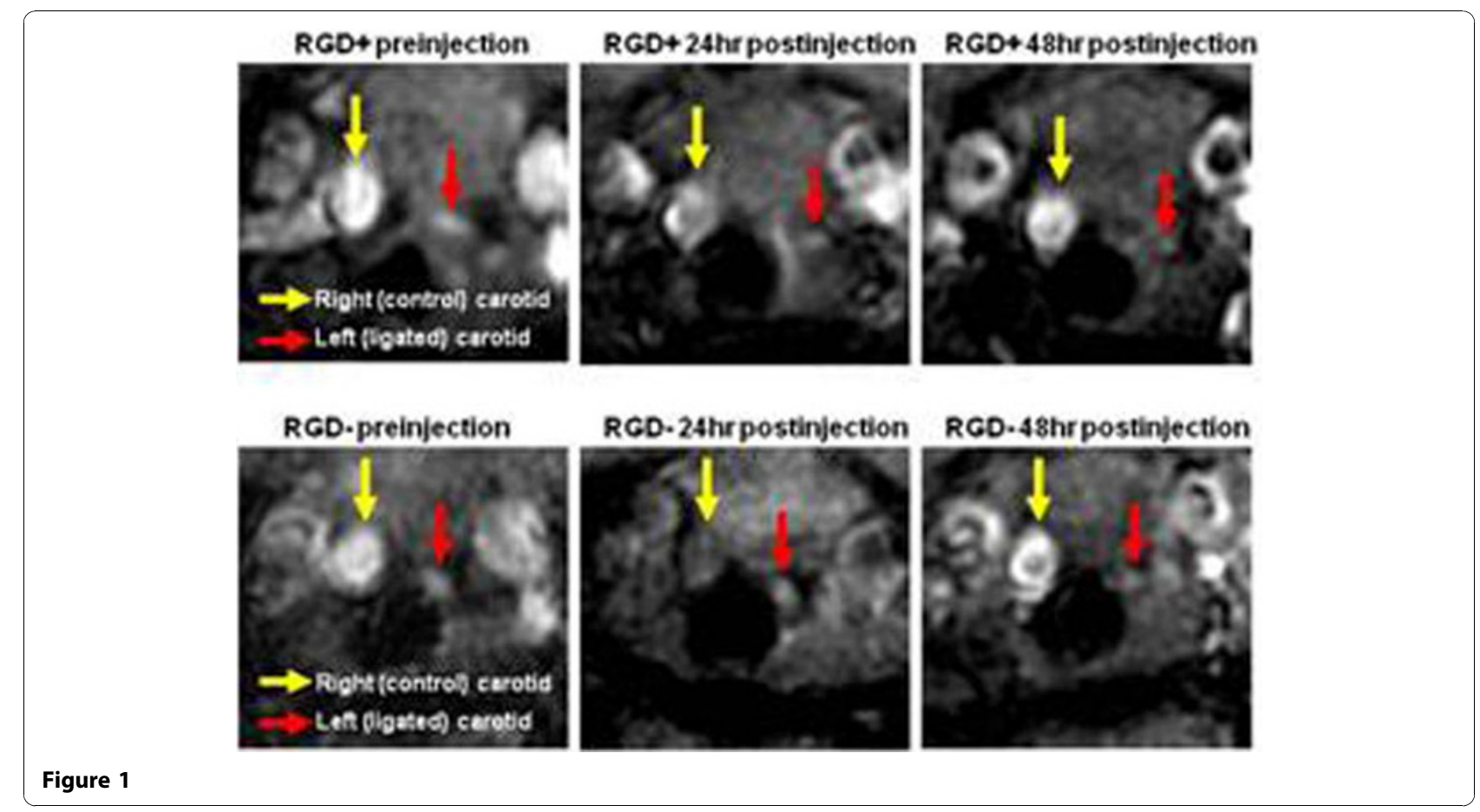

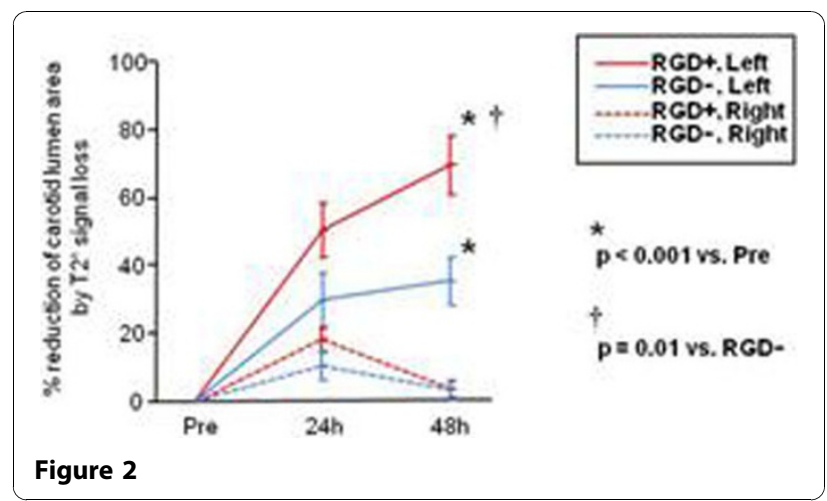

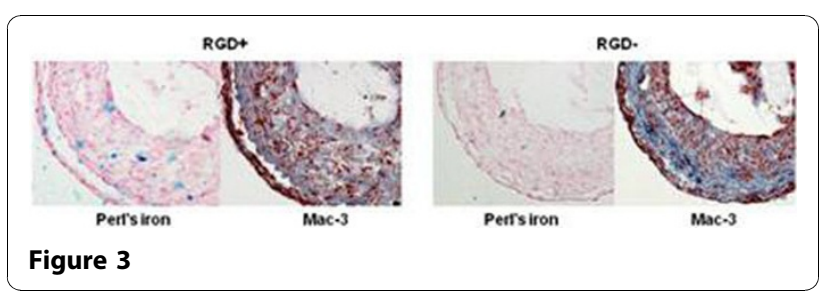

\section{Author details}

${ }^{1}$ Stanford University School of Medicine, Stanford, CA, USA. ${ }^{2}$ Montana State University, Bozeman, MT, USA.

Published: 2 February 2011

doi:10.1186/1532-429X-13-S1-P373

Cite this article as: Kitagawa et al:: RGD targeting of human ferritin iron oxide nanoparticles can enhance in vivo carotid MRI of experimental atherosclerosis. Journal of Cardiovascular Magnetic Resonance 201113 (Suppl 1):P373.
Submit your next manuscript to BioMed Central and take full advantage of:

- Convenient online submission

- Thorough peer review

- No space constraints or color figure charges

- Immediate publication on acceptance

- Inclusion in PubMed, CAS, Scopus and Google Scholar

- Research which is freely available for redistribution 